\title{
Link from hygiene to allergies gains support
}

\section{Erika Check, Washington}

Researchers have confirmed that a pristine environment can contribute to allergies in small children - and thrown up new questions about the underlying causes of allergic disease.

The 'hygiene hypothesis' proposes that germ-free environments lie behind the huge increase in asthma and allergies seen in the West since 1960. Studies presented this week at the annual meeting of the American Academy of Allergy, Asthma and Immunology in San Francisco fired debate on one aspect of the hypothesis: can immune responses to single allergens protect against other allergens in later life?

Researchers have found that keeping a cat in a young child's house reduces the risk of cat allergies in later life. But they disagree about whether cats also protect against non-cat allergies.

In a study of 224 children in New Zealand, those with a cat in the house reacted less to cat and dog allergens than they did to dust mite allergens, the meeting heard. The study group, led by Julian Crane of the Wellington School of Medicine and Health Sciences, found that different immune-system molecules responded to the cat allergens than to other allergens. Crane and his colleagues say this hints at the immune-system response that protects against cat allergies.

They also believe their work shows that the cat response is not universally protective. "There's a very strong cat effect that can be cat-specific," says immunologist Thomas Platts-Mills of the University of Virginia in Charlottesville, who worked on the study.

The data contradict a study in which children who lived in a home with two or more cats or dogs appeared to gain protection against many allergies (D. R. Ownby et al. J. Am. Med. Assoc. 288, 963-972; 2002). But despite the results of that study, many researchers argue that different allergens affect the immune system in distinct ways. For instance, research published this month showed that mice infected with the influenza virus were predisposed towards developing allergic asthma (M. E. Dahl et al. Nature Immunol. 5, 337-343; 2004). In contrast, hepatitis A infections are associated with lower risks of allergies (J. J. McIntire et al. Nature 425, 576; 2003). Many researchers are trying to figure out why different antigens give these conflicting results.

The answer may lie in how children are exposed to allergens, Ursula Krämer of the Environmental Health Research Institute in Dusseldorf, Germany, told the meeting. Krämer's team studied 3,241 German chil-

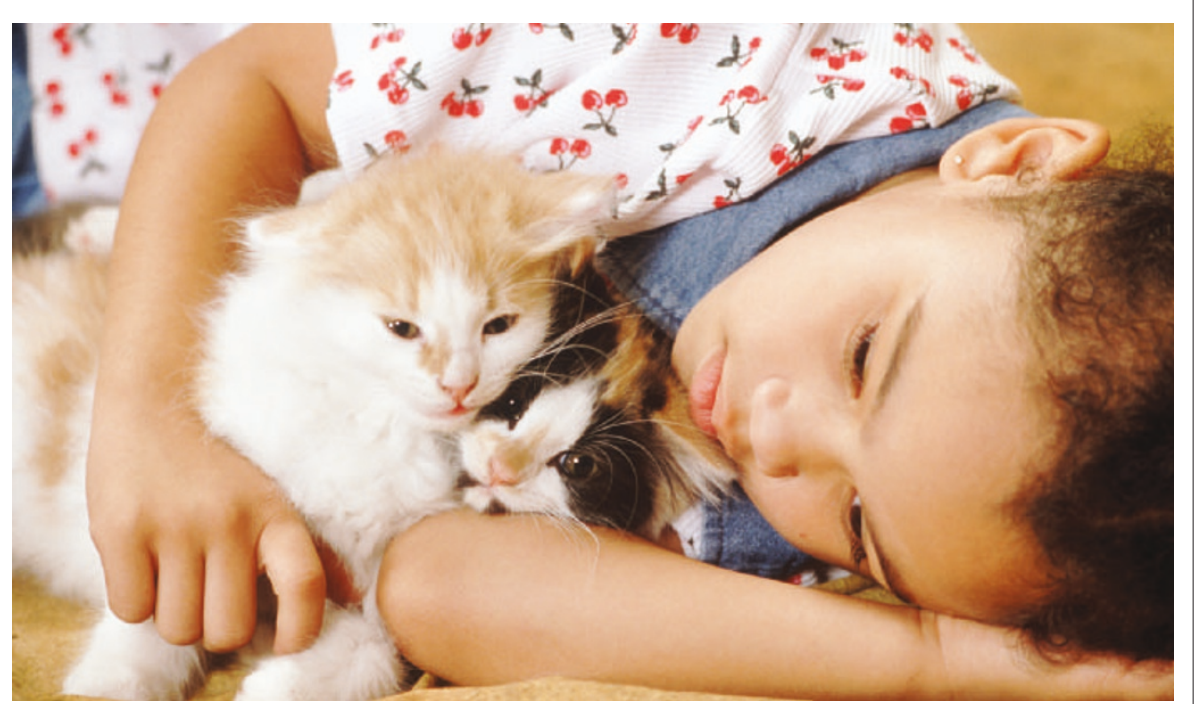

Furry friends: pet cats can protect children against allergies, but it's not clear how broad the benefit is.

dren and found that those with more educated parents were more likely to develop cat allergies after keeping a cat in the house. The team thinks that the relationship might be due to behavioural differences, such as how much contact the child has with the pet.

Lacking a good understanding of the mechanisms behind allergic disease, scientists struggle to explain these studies. But Kenneth Adams, chief of the asthma and inflammation section at the National Institute of Allergy and Infectious Diseases in Bethesda, Maryland, says that a more hygienic Western world has clearly influenced rates of allergic disease - but the effect also varies with different allergens, socioeconomic factors and genetics.

"The basic notion that infection can protect against sensitization is probably a huge oversimplification," says Adams.

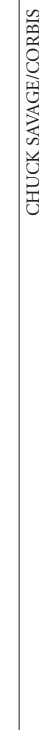

\section{Biology hogs the science budget, senator complains}

\section{Erika Check, Washington}

Money tensions on Capitol Hill erupted into

farce last week when researchers at the National Institutes of Health (NIH) were branded "pigs" by a senior senator during a budget debate.

"The NIH is one of the best agencies in the world," Senator Pete Domenici (Republican, New Mexico) told colleagues at the 11 March debate. "But they have turned into pigs. You know, pigs! They cannot keep their oinks closed. They send a senator down there to argue as if they are broke." Observers said that Domenici also used his hand to mime a pig's snout in front of his face and wiggled his fingers. "Will you listen to what has happened to the NIH in five years and tell me that they should get this much money?" he said.

Domenici was responding to Arlen Specter (Republican, Pennsylvania) - one of the NIH's main champions in the Senate - who successfully proposed that the budget resolution for 2005 incorporate a $\$ 1.3$ billion boost for the NIH. This is $\$ 536$ million more than President Bush has proposed for the agency. The resolution guides the appropriations subcommittees who determine actual spending levels.

But the proposal outraged Domenici, a strong supporter of physical-sciences research whose home state houses two huge nuclear weapons laboratories, Los Alamos and Sandia. Backers of the physical sciences have become increasingly frustrated in recent years by the failure of other research agencies to attract the kind of increase obtained by the NIH. These feelings had seldom been publicly expressed, however until Domenici's outburst.

The NIH is one of the few agencies apart from defence and homeland security that could get a big budget increase next year. On 2 February, President Bush proposed that the agency should get $\$ 28.6$ billion in the 2005 fiscal year, which starts in October, a $2.6 \%$ increase on the 2004 budget. But NIH advocates want $8-10 \%$, to help the biomedical research agency sustain the momentum created by the doubling of its budget between 1998 and 2003. 